\title{
Addressing Farmer's Perceptions-attitudes and Constraints to Adopt Agroforestry adjacent to the Coastal Belt of Sundarbans, Bangladesh
}

\author{
Md. Akramul Islam, Laila Abeda Aktar, S. M. Rakibul Jubair, Tanmoy Dey, and Rahul Biswas
}

\section{ABSTRACT}

Agroforestry is receiving a win-win strategy for low-income countries through increasing attention in Bangladesh especially in the coastal region because of its capacity to address some of the negative consequences of intensive agriculture with sustainable perceptions, attitudes, and management through farmers both locally and globally. As the actual uptake and maintenance of agroforestry in proximity to the coastal area by farmers remains low and that is why this research work investigates agroforestry practices e.g., Homestead agroforestry, boundary plantation, mixed plantation, cropland agroforestry, agrisilvicultural systems, Agro-aqua silviculture, and Agro-aquaculture systems on a sustainable basis with a view to find out the farmers 'perceptions and attitudes through identifying their constraints and problems with potential opportunities to adopt agroforestry in Satkhira district of Bangladesh. A sample of 80 respondents selected randomly was interviewed through a semi-structured interview schedule individually and a multistage random sampling technique was adopted to conduct the study. Therefore, results revealed that middle-aged farmers (3650) $(\mathbf{4 6 \%})$ are interested in agroforestry practice than a traditional practice. The adoption of younger (26-35) $35 \%$ farmers is increasing day by day since they have had more schooling than the older generation or perhaps have been exposed to new ideas as a migrant. Illiteracy $(56 \%)$ has primary level of education) is the main reason for non-adoption of agroforestry. The farmers $(28 \%)$ they taken lease from other people who have no own land they are not interested in agroforestry. Farmers $(47 \%)$ are interested in agro-aquaculture practice, because high cash return get from this practice. About $\mathbf{6 8 . 7 \%}$ respondents have taken positively agroforestry practice, but they have no training skill or facility. If they get this facility, they are more interested in agroforestry practice. Finally result mentioned that $\mathbf{7 6 . 2 5 \%}$ respondents perceived agroforestry positively and most of the farmer's $(68.7 \%)$ have positive attitude towards it whilst maximum farmers $(80 \%)$ think agroforestry system should be expanded. This research indicates that agroforestry is a catalyst factor which can be adopted more through directed programs, policies and practices by government and its related agencies from this positive perceptions and attitudes of this research. Thus, agroforestry is a sustainable potential land use in the long term through combination of intrinsic and extrinsic factors interact and drive adoption can help integrating technologies appropriately to ensure sustainability adjacent to the coastal region of Sundarbans of Bangladesh.

Keywords: Agroforestry, attitude, constraints, perception, Sundarbans, Sustainable.
Submitted : May 20, 2021

Published : August 29, 2021

ISSN: $2684-1827$

DOI: 10.24018 /ejfood.2021.3.4.304

Md. Akramul Islam*

(e-mail: akramkukhulna@gmail.com)

Laila Abeda Aktar

(e-mail: lailaabeda@gmail.com)

S. M. Rakibul Jubair

(e-mail: smrjubair@gmail.com)

Tanmoy Dey

(e-mail: tanmoyfwt100518@ gmail.com)

Rahul Biswas

(e-mail: rahulkufwt@ gmail.com)

*Corresponding Author

\section{INTRODUCTION}

Bangladesh is characterized by a relatively small natural resource base and a population of more than 160 million. The official forest coverage of the country is about $17 \%$ [1], with per capita forestland of around 0.02 ha - one of the lowest in the world [2]. Moreover, the country's public forests are often degraded and unevenly distributed or spatially scattered (out of 64 districts of the country, 28 districts have no state forests) [3]. Due to its high population density, poverty, and unemployment the deforestation rate in the country is also one of the highest in tropical Asia [4]. Forest cover in Bangladesh has declined from about $15 \%$ of the total land area to 5\% [5]. More than $90 \%$ of the state-owned forest land is concentrated in 12 districts in the eastern and southwestern regions of the country and out of 64 districts, 28 districts have no state-owned forest at all [6] and more than 80 percent of the total population lives in rural areas and a greater percentage of them live below the poverty line [1]. The primary cause of this destruction of forest is due to heavy 
population pressure and another secondary cause, lack of integrated planning for the development of multiple resource bases with the active participation of people [7]. A combination of rapid losses in forest cover and reduced access to forests due to conservation regulations have stimulated the need for an alternative source of biomass fuel [8], [9]. Bangladesh is experiencing deforestation, degradation of existing forest, biomass shortage and decline in livelihood status of people living adjacent to the Sundarbans mangrove forest [7] which is highly dynamic ecosystem as coastal ecosystem [10] and represents $4.07 \%$ of the land mass and $40 \%$ of the total forest area of Bangladesh [11]. The economic growth leads on the bases of utilization and exploitation of the natural resources [9]. At the southern part of the country there stands Sundarbans with an area of 0.601 million ha. The growing stock of the Sundarbans forest has depleted from 20.3 million cum. in 1960 [12] to 10.6 million cum. in 1984 [13]. Despite the many ecosystem services mangrove provides, deforestation and land conversion pressures on these coastal ecosystems are high because approximately $44 \%$ of global population resides within $150 \mathrm{~km}$ of the coastline [10]. Mangroves are considered as a natural barrier protecting the lives and property of coastal communities [1], [11]. Establishment of plantation in the poorly regenerated areas of the Sundarbans for the enrichment of ecosystem and biodiversity of the Sundarbans to mitigate the climate change issues [11], [6]. NTFPs are also important parts of biodiversity and are considered as component of livelihoods in terms of their economic, social, and ecological value [1]. At the same time coastal area adjacent to Sundarbans is a blessing to local people with its infinite resources and services [1], [9]-[11] which provides cultural services (tourism)[14] and people are used to Non Timber Forest Products (NTFPs) directly and indirectly [9], [1].

In 2003, the per capita land availability was 0.10 hectares, declining from 0.14 hectares in 1992, which puts heavy pressure on land for human habitation and crop production in Bangladesh [15]. The dependency of the people in this coastal area is much greater on the Sundarbans for their survival, employment, income generation, and other important purposes [16]. Special effort is needed to increase the profitability of agriculture in Bangladesh and thereby reduce rural poverty, which requires a $4 \%$ growth rate in the agricultural sector [17]. Coastal management is important considering different services such as medicinal values, aesthetic values, biodiversity point of view, climate-resilient coastal afforestation, and after all to accelerate sustainable livelihood patterns adjacent to the people of Sundarbans [10], [6] as well as contributing to the local and national economy [1], [11]. Increasing rapid growth of population creates new pressure on the various limited resources like forest and forest and land resources. Therefore, an alternative livelihood pattern is essential to increase socio-economic condition directly or indirectly in the coastal belt of Sundarbans[9], [13]. A management system, therefore, needs to be devised which is capable of producing food from marginal agricultural land and also capable of maintaining and improving the quality of the producing environment [18]. Agroforestry is an integral part of the rural livelihood systems in Bangladesh and plays a key role in providing household food and energy, security, income and employment generation, investment opportunities and environmental protection as well as sustainable livelihood pattern [6] which provides different services such as medicinal values, aesthetic values, biodiversity point of view, climate resilient coastal afforestation and after all to accelerate sustainable livelihood pattern adjacent to the coastal people of Sundarbans [10], [6]. The major service function of agroforestry is its role in soil management, including control of erosion and maintenance and improvement of soil fertility [7]. In addition, the interest in the management of traditional agroforestry has declined and multi-functional land use is lacking in many systems[19] and to meet this demand agroforestry is a dynamic ecologically based natural resources management system that through the integration of trees and sustains production for increased social, economic and environmental benefits for land users at all levels [6], [20]. Besides due to population pressure, it is difficult to allocate agricultural lands for growing forest [21] and that is why agroforestry can be a sustainable management system to meet the demand of forest produces and also to reduce the poverty for the people of this region [6]. The lack of knowledge that farmers have about agroforestry is an obstacle to the implementation of the system and many farmers in industrialized countries have little or no knowledge about trees[22]. Intrinsic factors such as the knowledge, perceptions, and attitudes of the potential adopter towards the innovation play a key role in agricultural sector [23]. Localized forms of perception depend on societal, ethnic, and economic situations in which people experience risk as perceptions influence behavior [24]. A profound understanding of farmers' perception of climate change is significant for policy-makers when determining adaptation strategies. Perceived susceptibility refers to a person's feeling of being affected by a particular problem, which may lead to a greater change in attitudes [25]. Perceived severity refers to consciousness of the intensity of the problem (CEP) which may state the seriousness of the problems. Farmers' practices will form a major source of information that the government can use to address the falling productivity levels. Hence, it is important to investigate farmers' perceptions, awareness, attitudes, and adaptation behavior towards agroforestry. The central aim of this research work is to find out the farmer's attitude and perceptions on sustainable basis towards the scientific farming system like agroforestry. Besides, it accelerates to identify the existing agroforestry practice of research area, to know farmer's perception (realization or appreciation) and attitude (intention or viewpoint) about the agroforestry practice and to know the problems and constraints faced by the farmers to adopt agroforestry in the coastal belt Sundarbans, Bangladesh.

\section{MATERIALS AND METHODS}

\section{A. Selection of the Research Area}

The research was conducted at Satkhira district of Bangladesh from January 2018 to January 2019. An exploratory survey was conducted in Satkhira district to explore information regarding the demographic profile of 
respondents, annual income of respondents, and cultivation practice, attitudes, and perception towards agroforestry practice and their constraints. During the research work, a multistage random sampling technique is adopted. Satkhira district was selected purposively as the study area which is the first sampling unit. Four Upazilas namely 1. Shayamnagor, 2. Tala, 3. Khaligong, 4. Satkhira Sador was selected purposively, and these are the second sampling unit. Then from each Upazila two Unions were selected which are the third sampling unit. Then from each union two villages are selected randomly. These villages are the fourth sampling unit and five families are selected randomly from each village. A total of 80 families were contacted to participate in the face-to-face interview. All sampling units are given in Table I.

TABLE I: NAME OF ALL SAMPLING UNITS IN THE RESEARCH AREA

\begin{tabular}{|c|c|c|c|}
\hline $\begin{array}{l}\text { Name of the } \\
\text { District (First } \\
\text { sampling } \\
\text { unit) }\end{array}$ & $\begin{array}{l}\text { Name of the } \\
\text { Upazilas } \\
\text { (Second } \\
\text { sampling unit) }\end{array}$ & $\begin{array}{l}\text { Name of the } \\
\text { Uninons } \\
\text { (Third } \\
\text { sampling unit) }\end{array}$ & $\begin{array}{c}\text { Name of the } \\
\text { Villages } \\
\text { (Fourth sampling } \\
\text { unit) }\end{array}$ \\
\hline \multirow{7}{*}{ Satkhira } & \multirow{2}{*}{ Shayamnagor } & Munshigong & $\begin{array}{c}\text { Munshigong } \\
\text { Gelekhali }\end{array}$ \\
\hline & & Burigoalini & $\begin{array}{c}\text { Abadcondipur } \\
\text { Bonbitola }\end{array}$ \\
\hline & \multirow[t]{2}{*}{ Tala } & Talasadar & $\begin{array}{l}\text { Kharerdanga } \\
\text { Kismotghona }\end{array}$ \\
\hline & & Tetulia & $\begin{array}{c}\text { Agarjara } \\
\text { Tetulia }\end{array}$ \\
\hline & Khaligong & Ratonpur & $\begin{array}{l}\text { Mihajkathi } \\
\text { Ratanpur } \\
\text { Parulgacha } \\
\text { Kusulia }\end{array}$ \\
\hline & \multirow{2}{*}{$\begin{array}{l}\text { Satkhira } \\
\text { Sador }\end{array}$} & Labsha & $\begin{array}{c}\text { Khejurdanga } \\
\text { Taltola }\end{array}$ \\
\hline & & Agordari & $\begin{array}{l}\text { Abaderhat } \\
\text { Sialdanga }\end{array}$ \\
\hline
\end{tabular}

\section{B. Selection of the Respondents}

In total 80 respondents (each respondent selected randomly) were selected for the survey randomly. A detailed socio-economic survey was conducted to assess educational status, land status, occupation, and income. Respondents are selected randomly from villages.

\section{Measurement of Perceptions and Attitudes towards Agroforestry}

A Likert scale [26] is a psychometric scale commonly involved in research that employs questionnaires. It is the most widely used approach to scaling responses in survey research, such that the term is often used interchangeably with a rating scale, or more accurately the Likert-type scale, even though the two are not synonymous. When responding to a Likert questionnaire item, respondents specify their level of agreement or disagreement on a symmetric agree-disagree scale for a series of statements. Thus, the range captures the intensity of their feelings for a given item.

The main focus was on obtaining data on farmer's perceptions and attitudes towards agroforestry of Satkhira district in Bangladesh. In order to obtain relevant information, the interview schedule was carefully designed keeping in mind the objective of the study. The primary data were collected by conducting a survey work with a well- prepared structured questionnaire. The secondary sources of data including books, journals, various publications of Government, institutions, and other organizations, articles of local and national newspapers, and other research papers on the same or similar issues have been used for data collection. In addition to this, the internet has also been used as a secondary source of data collection. After collecting information from primary and secondary sources, data are processed and analyzed by MS word and MS excel.

\section{RESUlTS}

\section{A. Socio-economic Characteristics of the Respondents}

The biographical characteristics include age, education, and source of income. Different studies revealed that the socio-economic characteristics had much influence on the adoption behaviour regarding new practices [27].FAO, (2013) [5]; reported that the innovators and early adopters were those who were higher in their socio-economic status than those who were lower in their socio-economic status.

\section{1) Age Distribution of Respondents}

Farmers are divided into four categories. Major farmers $(46.25 \%)$ were middle-aged. It is important to note that the middle age group in the context of the respondents (36-50) $46.25 \%$ forms the bulk of agroforestry practitioners indicating the potential of this group as the most important clientele who could be involved in agroforestry practices and technologies. Younger (26-35) 35\% farmers are likely to adopt new technology since they have had more schooling than the older generation or perhaps have been exposed to new ideas as a migrant.

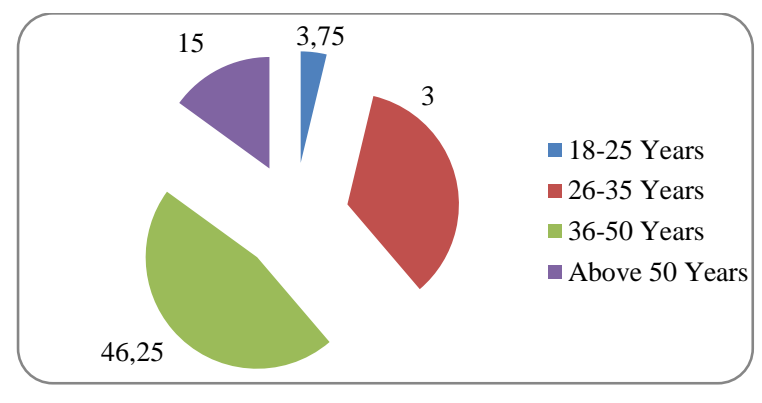

Fig. 1. Age distribution of respondents in the research area.

\section{2) Level of Education of Farmer's in the research area}

The high level of literacy rate would result in the increase of agroforestry technology. Education is an important socioeconomic variable that may make a farmer more receptive to advice from an extension agency or more able to deal with the technical recommendation that requires a certain level of literacy.

TABLE II: EDUCATION LEVEL OF THE FARMER'S IN THE RESEARCH AREA

\begin{tabular}{ccc}
\hline Education Level & No. of Farmers & $\begin{array}{c}\text { Percentage of } \\
\text { Farmers }\end{array}$ \\
\hline Primary & 45 & 56.25 \\
Secondary & 21 & 26.25 \\
Above Secondary & 9 & 11.25 \\
Illiterate & 5 & 6.25 \\
\hline
\end{tabular}

Table II indicated (6\%) respondents were illiterate. $56 \%$ were primary school level, while only $26 \%$ were up to 
secondary and $11 \%$ above. Table II indicated a majority of the respondents $(56 \%)$ have a primary level of education. This study showed that illiteracy was also the main areas on for non-adoption of agroforestry by farmers. The farmers considered this practice confuse for their agricultural crops due to lack of education and awareness.

\section{3) Size of land holding}

The land holding size was categorized in three groups i.e., land less, less than 1 acres, and more than 1 acre. The land, which the farmers own and manage, was asked. The data given in Table III indicated that mostly the respondents $(61.25 \%)$ were small farmers having land holding less than 1 acre and $(13.75 \%)$ farmers were landless and $(25 \%)$ farmers were more than 1 acre. These results show that mostly the farmers $(61.25 \%)$ in the study area have small land holding (>1 acre). The farmers $(25 \%)$ are more interested to grow cereals/trees for their domestic use and cash crops (Table III).

\begin{tabular}{ccc}
\multicolumn{2}{c}{ TABLE III: SIZE OF LAND HOLDING IN THE RESEARCH AREA } \\
\hline Land holding size & No. of Farmers & $\begin{array}{c}\text { Percentage } \\
\text { of Farmers }\end{array}$ \\
\hline Landless & 11 & 13.75 \\
Less than 1 acre & 49 & 61.25 \\
More than 1 acre & 20 & 125 \\
\hline
\end{tabular}

\section{B. Land Tenureship}

The land tenureship (Fig. 2) shows that $72.5 \%$ of respondents have their own land. $15 \%$ of respondents take land by others which is known as borga system. $8.75 \%$ of respondents give land to another people by borga system and $3.75 \%$ of people take lease from Govt. land or other people. By this study, we know that the people (72\%) who have their own land for agricultural practice, are interested in agroforestry practice. But they have no own land (28\%) they are not interested in agroforestry practice. The people (28\%) who have no own land cultivate on other's land, and they think no need for permanent or semi-permanent practice on other's land. They practice traditional monoculture (Fig. 2).

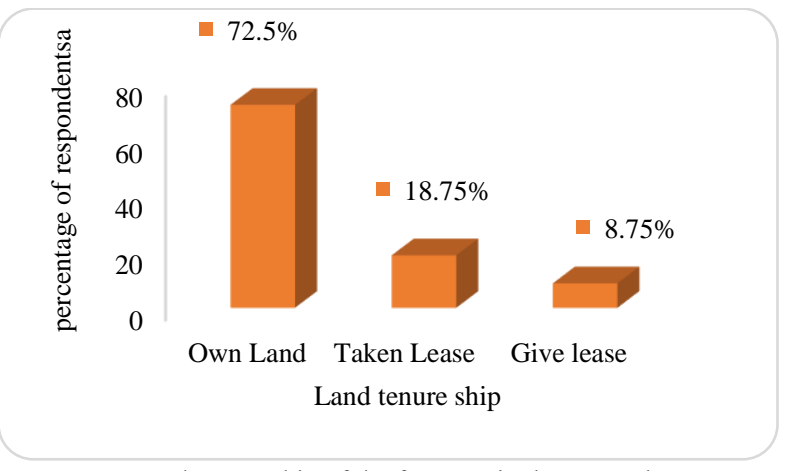

Fig.2. Land tenure ship of the farmer's in the research area.

\section{Agricultural and Agroforestry Land Use System}

1) Land use system and the type of crops cultivated in the study area

The land-use systems in the study area include crop production and fish production system. Agroforestry practices undertaken by farmers in the study area include boundary plantation, mixed cropping, and agro-aquaculture, etc. (Table V). The annual crops cultivated in the land use system included papaya, banana, blackberry, coconut, betel- nut, paddy, wheat, mustard oil seed, potato, betel leaf, masur dal, mug dal, til, begun, lalshak, bean, khirai, piaj, corolla, etc. The trees in the land use system included mango, jackfruit, citrus sp, khejur, coconut tree, mehegoni, kul, rain tree, kadam, etc. (Table IV).

\begin{tabular}{cc} 
TABLE IV: TYPES OF ANNUAL CROP USED IN AGROFORESTRY PRACTICE \\
\cline { 2 - 2 } Local Name & Scientific Name \\
\hline Potato & Solanumtuberosum \\
Paddy & Oryza sativa \\
Wheat & Triticumaestivum \\
Masur & Lens esculenta \\
Mustard & Brassicaspp \\
Bean & Lablab purpureus \\
Brinjal & Solanummelongena \\
\hline
\end{tabular}

TABLE V: TYPES OF CROPS GROWN IN THE STUDY AREA

\begin{tabular}{ccc}
\hline Type of crops & No of farmers & $\begin{array}{c}\text { Percentage of } \\
\text { farmers }\end{array}$ \\
\hline Annual crops & 19 & 15.2 \\
Annual crop + Tree & 12 & 8.8 \\
Annual crop + Fish & 24 & 20 \\
Annual Crop + Tree + Fish & 16 & 14.4 \\
Annual Crop + Tree + & 9 & 5.6 \\
Fish+ duck & & \\
\hline
\end{tabular}

Most farmers had the desire to grow annual crops in order to provide annual household consumption. They also wanted to increase income by incorporating trees. By this study, we found that people are interested in agro aquaculture (20\%) paddy with fish (Prawn, shrimp) because of immediate high cash return (Table V).

\section{2) Agroforestry Practice in the study area}

The people of the study area have a tradition of practicing agroforestry and their practices have been reinforced by the need for socio-economic and environmental sustainability. Three common agroforestry types were found in the study area.

1. Homestead agroforestry practice.

2. Cropland agroforestry Practice in the research area: Boundary Plantation, Mixed Cropping, Agri-silviculture, Agroaquaculture, Agro-aqua-silviculture.

3. Monoculture practice.

1. Homestead agroforestry

Home gardens, mixed plantings of annual and tree crops around dwellings, are a common type of multi-storey agroforestry system. Home gardens also provide a pleasant, shaded living area. Many farmers already grow multipurpose trees in their home gardens for flowers, fruits, and seeds, trees, fish, agricultural crops, cattle, etc. In the study area almost $100 \%$ of farmers' practice home gardens traditionally.

\section{Cropland agroforestry}

Cropland agroforestry combines the production of agricultural crops and trees in the cropland through intercropping. Three cropland agroforestry types were found in the study area.

\subsection{Boundary Plantations}

Boundary plantations combine perennial, preferably leguminous trees or shrubs grown around an arable crop. Boundary plantations as windbreaks also protect crops. Timber trees are planted along boundaries spaced at $6 \mathrm{~m} \times 6 \mathrm{~m}$ or $5 \mathrm{~m} \times 5 \mathrm{~m}$ to reduce excessive shading of annual crops, while for fruits trees $4 \mathrm{~m} \times 4 \mathrm{~m}$ is ideal and trees for fuelwood can be planted at $3 \mathrm{~m} \times 3 \mathrm{~m}$. Commonly used trees (Table VI) 
are grown along field boundaries or bunds of paddy, wheat fields. Farmer's perception and my observation (41\% respondents) coconut and paddy are the best combination for boundary plantation in Satkhira district (Fig. 3).

\subsection{Mixed Cropping}

Mixed Cropping constitutes one of the main agricultural land-use practices in the study area. Most of the farmers (6\%) contain various annual crops, which is commonly referred to as Mixed Cropping system (Table VI). In the study area, wheat and mustard are the common practice in mixed cropping systems (Fig. 3). These farmers have a multicropping system and provide farm stability, and efficiency in the use of land and labour, as well as ensure annual security.

TABLEVI: TYPE OF CROPS GROWN IN THE STUDY AREA

\begin{tabular}{|c|c|c|}
\hline $\begin{array}{c}\text { Agroforestry } \\
\text { Practice }\end{array}$ & Types of trees & $\begin{array}{c}\text { Types of } \\
\text { crops/Fish }\end{array}$ \\
\hline $\begin{array}{l}\text { Boundary } \\
\text { plantation }\end{array}$ & $\begin{array}{c}\text { Khejur, Coconut, } \\
\text { Babla, Betel - Nut, } \\
\text { Akasmoni, Mahagoni, } \\
\text { Neem, Rain tree }\end{array}$ & $\begin{array}{l}\text { Paddy, Jute, } \\
\text { Wheat, Papaya, } \\
\text { Banana, Halud. }\end{array}$ \\
\hline Mixed Cropping & $\begin{array}{l}\text { Supari, Coconut, } \\
\text { Mahagoni, Sajina, } \\
\text { Khejur, Tal, Jam, } \\
\text { Kamrang, Neem, } \\
\text { Jackfruit, etc. }\end{array}$ & $\begin{array}{l}\text { Rice, Maize, } \\
\text { Kachu, Halud, } \\
\text { Banana, Ginger, } \\
\text { Tomatoes, } \\
\text { Cabbage and } \\
\text { Marich etc. }\end{array}$ \\
\hline Monoculture & $\mathrm{X}$ & $\begin{array}{c}\text { Aman Paddy, } \\
\text { Boro Paddy }\end{array}$ \\
\hline $\begin{array}{l}\text { Agrisilvicultural } \\
\text { Systems }\end{array}$ & $\begin{array}{l}\text { Rice, Maize, Kachu, } \\
\text { Halud, Banana, } \\
\text { Ginger, Tomatoes, } \\
\text { Cabbage and } \\
\text { Marichetc }\end{array}$ & $\begin{array}{c}\text { Supari, Coconut, } \\
\text { Mahagoni, Sajina, } \\
\text { Khejur, Tal, Jam, } \\
\text { Kamrang, Neem, } \\
\text { Jackfruit, etc. }\end{array}$ \\
\hline $\begin{array}{c}\text { Agro- } \\
\text { Aquasilviculture }\end{array}$ & $\begin{array}{l}\text { Coconut, Betel nut, } \\
\text { Supari, Coconut, } \\
\text { Mahagoni, Sajina, } \\
\text { Khejur, Tal, Jam, } \\
\text { Kamrang, Neem, } \\
\text { Jackfruit,etc }\end{array}$ & $\begin{array}{c}\text { Aman Paddy, } \\
\text { Boro Paddy, } \\
\text { Prawn, Carp Fish }\end{array}$ \\
\hline agro-aquaculture & $X$ & $\begin{array}{c}\text { Aman Paddy, } \\
\text { Boro Paddy, } \\
\text { Prawn, Carp Fish }\end{array}$ \\
\hline
\end{tabular}

\subsection{Agrisilvicultural systems}

In this system, agricultural crops are intercropped with tree crops in the interspace between the trees. Under this system agricultural crops can be grown up to two years under protective irrigated condition and under rained farming up to four years. In the study area Boroi (Ziziphus mouritiana) are mixed with lalshak, Tal (Borasus flabelifer), Betel nut (Areca catechu) are mixed with Betel leaf. In the study area, $8 \%$ of respondents are practicing this agri-silvicultural system (Fig. 5, Table VI).

2.4. Agro-aqua silviculture and Agro-aquaculture systems In this system, various trees and shrubs preferred by farmers are planted on the boundary and around fishponds. The main role of this system is fish production and bund stabilization around fishponds. In the study area, $22.5 \%$ of farmers are related to agro-aqua culture practice. Growing crops and fish together raise productivity and helps relieve pressure on land and water resources. In the study area, $47 \%$ of farmers are related in agro-aqua culture practice (Fig. 3).

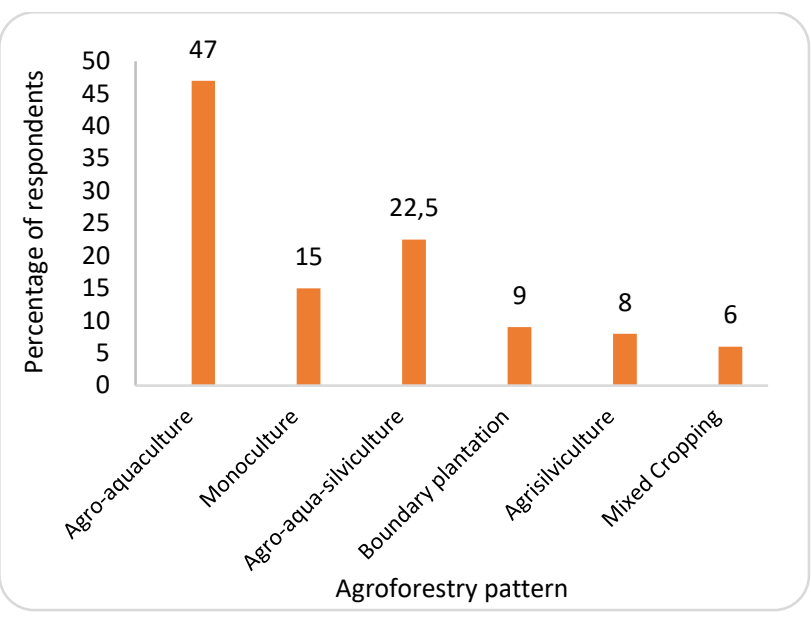

Fig. 3. Percentage of respondents of agroforestry practice in the research area.

\section{Perception of Farmers on Agroforestry System}

Perception is a way of seeing, understanding, and interpreting something, it is the deeper natural understanding and awareness that is usual. In this thesis paper, perception indicates that the farmer's awareness and understanding of the agroforestry systems in Satkhira district (Fig. 4). The farmers of Satkhira district practices agroforestry traditionally within their agricultural cropland as well as their homestead. They perceived that the practice is done for their own satisfaction and household consumption. In the study area farmers thinks positively about agroforestry systems (Fig. 4). The farmers also perceived that agroforestry is more profitable and less risky, than other agricultural options (Fig. 4). Aside from the tree species, the advantage of agroforestry is the early return from non-timber crops that are interplant with the trees and also other main reason for perceived the system because of the multiple benefits the farmers gain from the crop-tree combination (Fig. 4). On the other hand, a few farmers are not willing to perceive the agroforestry systems because of the main reasons are lack of capital, lack of interest, lack of knowledge on agroforestry systems, long term in profit earning, land of technical assistance, do not have suitable land for this cultivation practice, and unstable market price for agroforestry product.

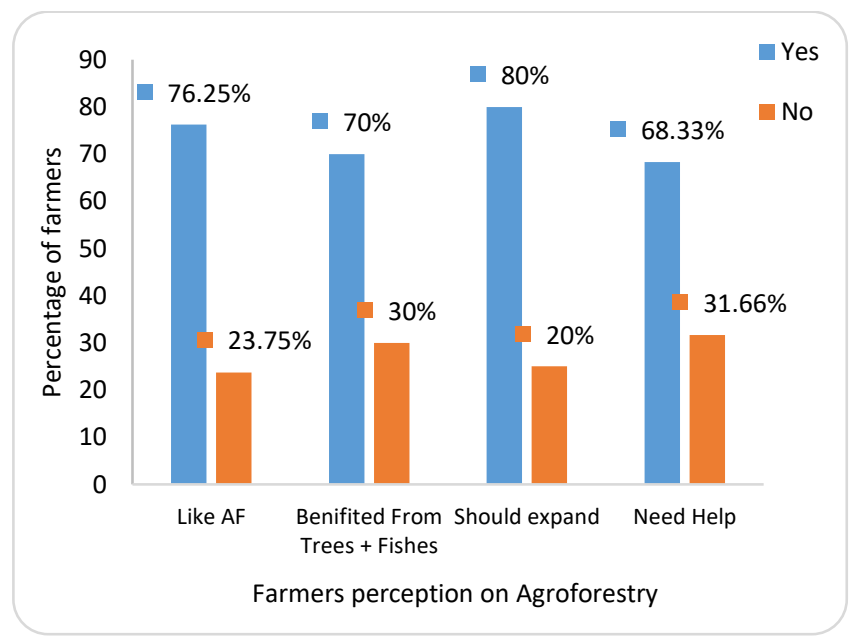

Fig. 4. Farmers perception on agroforestry in the study area. 
These results were encouraging, which showed that the farmers were realizing the importance of trees and fishes to meet their demand of protein, timber fuelwood, fodder requirements and increase the capital formation. In this figure, we found that $76.25 \%$ of respondents like agroforestry (Fig. 4). $70 \%$ of respondents perceived positively because they get more benefit from tree and fish than monoculture practice and $30 \%$ of people showed negative perception because they think traditional agricultural practice give more production. $80 \%$ of respondents said that agroforestry practice should expand (Fig. 4). 68.33\% of respondents said that they need help with this technology (Fig. 4). Finally, we found the majority of farmers had shown a positive perception of agroforestry.

\section{E. Farmer's Attitude towards Agroforestry}

The results revealed that the majority of the farmers had a favourable attitude towards agroforestry. The farmers of Satkhira in general had favourable to more favourable attitude towards agroforestry. In the study area, $68.7 \%$ of farmers have a more favourable attitude towards agroforestry practice (Fig. 5). The farmer who has no own land (23.75\%), they are not more interested in agroforestry practice. They practice agroforestry on a small scale. Some people who are not aware of agroforestry technology (8\%) (Fig. 5) show neutral attitude to agroforestry practice.

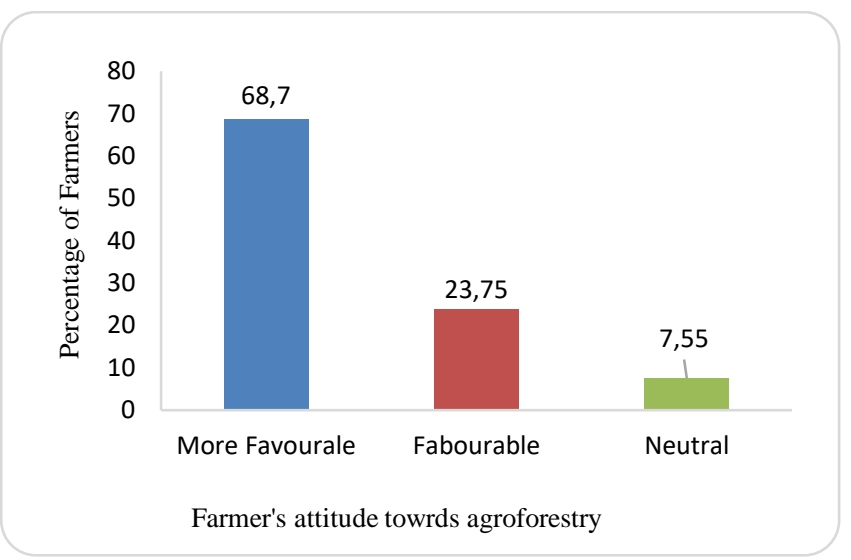

Fig. 5. Farmers' attitude towards agroforestryin the study area.

\section{F. Status of Agroforestry Adoption on Land}

In Satkhira district at first, some farmers had started agroforestry practice when they got more benefit from agroforestry practice on the same piece of land compared to before practice. After then other farmers have observed they also involved agroforestry practice in this way agroforestry practice becoming popular in Satkhira district. In the study area last 1-3 years (76\%) the adoption to agroforestry is higher than last $4-5$ years $(22.5 \%)$ (Table VII).

\begin{tabular}{ccc}
\multicolumn{2}{c}{ TABLE VII: STATUS OF AGROFORESTRY ADOPTION ON LAND } \\
\hline Adoption of years & No. of Farmers & $\begin{array}{c}\text { Percentage of } \\
\text { Farmers }\end{array}$ \\
\hline $1-3$ & 61 & 76.25 \\
$4-5$ & 18 & 22.5 \\
No response & 19 & 23.75 \\
\hline
\end{tabular}

\section{G. Constraints Faced by Respondents in the Adoption of Agroforestry}

The respondents were asked to report about the problems, being faced by them in the adoption of agroforestry. Their responses are given in Table VIII which indicated that all the respondents reported unawareness, lack of education, technical skills, capital, technical assistance, interest, and marketing and transportation facilities as the main hindrances in the adoption of agroforestry. These all constraints can be easily overcome by launching awareness campaigns, training workshops, providing technical assistance, and establishing marketing points. $40 \%$ of respondents are facing the problem of lack of technical skills (Table VIII).

TABLE VIII: PROBLEMS AND CONSTRAINTS FACED BY RESPONDENTS IN

\begin{tabular}{ccc}
\multicolumn{3}{c}{ THE ADOPTION OF AGROFORESTRY } \\
\hline Problems & Frequency & Percentage \\
\hline Lack of education & 5 & $\underline{4}$ \\
Lack of technical & 50 & $\underline{40}$ \\
skills & 19 & 15.2 \\
Lack of Land & 6 & 4.8 \\
Lack of training & 10 & 8 \\
Lack of agricultural/ & & 8 \\
forest officials & &
\end{tabular}

\section{H. Suggestions for the Adoption of Agroforestry}

Table IX manifested that almost all the respondents $(99.2 \%)$ suggested frequent visits of forest department staff. Out of 80 respondents, a majority of the respondents $(81.6 \%)$ suggested initiating some loan schemes or financial incentives for the promotion of agroforestry. A majority of the respondents $(52.8 \%)$ of the farmers wanted to increase extension education activities and establishing forest nurseries that are easily accessible for them, while $24.8 \%$ of the farmers suggested for training to plant trees on their farmlands. This data shows that the farmers are facing the problems like technical assistance, marketing of wood and non-wood products, and transportation facilities. If the forest department overcomes these necessary issues, the promotion of agroforestry can be done.

\begin{tabular}{ccc}
\multicolumn{2}{c}{ TABLE IX: SUGGESTIONS FOR THE ADOPTION OF AGROFORESTRY } \\
\hline Suggestions & No. of Farmer & $\begin{array}{c}\text { Percentage of } \\
\text { farmers }\end{array}$ \\
\hline $\begin{array}{l}\text { Increase extension } \\
\text { education activities } \\
\text { Frequent visits of forest } \\
\text { department Staff }\end{array}$ & 28 & 33.75 \\
$\begin{array}{c}\text { Training of farmers to } \\
\text { plant trees on } \\
\text { farmlands } \\
\text { Publicity in mass } \\
\text { media }\end{array}$ & 31 & 56.25 \\
\hline
\end{tabular}

\section{DISCUSSION}

Many studies have focused on measuring farmers' perceptions and attitudes of the importance of different aspects of the agricultural system in the world. Agroforestry is such a production system and livelihood which is socially reasonable and economically feasible through diversification of input and output which reflects that it is a sustainable 
system in Bangladesh [6].The International Institute for Tropical Agriculture [28], in collaboration with Nigeria's Institute of Agricultural Research, measured farmers' perceptions of soil degradation in the northern Guinea savanna of Nigeria and found that proper management of resources, good planning, and hard work are commonly perceived as distinguishing features of better farmers. Integrated Administration and Control System [29], [30] mentioned that "agroforestry is considered as an entire system." According to Meijer et al. [23], the characteristics of the external environment affect the development of knowledge, attitudes, and perceptions in the agricultural field. Farmer's intentions to adopt sustainable practices are explained by attitude, perceived control, and normative issues [24]. But such a study adjacent to the coastal region of Sundarbans in Bangladesh is essential as relative sea-level rise could be the greatest threat to mangroves Sundarbans [10]. In Bangladesh, Sundarbans mangrove lies in the delta of Ganges, Bramhmaputra and Meghna (GBM) [11]. Sundarbans in Bangladesh as a delta is inevitably significant in respect to alternate livelihood pattern as well socioeconomic conditions [9]. Sundarbans play a pivotal role in the coastal communities which are a blessing to local people with their infinite resources and services [10]. The coastal Sundarbans, a common property with an abundance of forest resources has the potentiality for making a positive contribution towards poverty reduction [1]. Despite the many ecosystem services mangrove provides, deforestation and land conversion pressures on these coastal ecosystems are high because approximately $44 \%$ of the global population resides within $150 \mathrm{~km}$ of the coastline [9]. People usually use fuelwood, honey, fish, golpata, and goran stick, shrimp fry, prawn, some fruit trees, nail, hantal, hogla, grasses, malia, molasses etc. from Sundarbans [1]. About 3.5 million people living around the Sundarbans and they depend directly or indirectly on this forest's ecosystem services [14]. In the absence of alternate resources village, people tend to exploit the natural forests [9]. If there are various ways of alternative income from the forest of Sundarbans, the resources depletion rate may be reduced [1]. The people in the study area directly or indirectly use the minor forest products of the Sundarbans which is adjacent to the research area [6]. Resources depletion of forest unavoidable as their needs and that of their livestock has to be met by the nearby forests [9]. If an alternate forestry activity in the community level is developed with their co-operation they would also be interested in protecting the natural forests especially the largest single tract mangrove forest of the world named Sundarbans [1] and agroforestry such alternate source used to define land-use systems that combine agricultural and silvicultural practices to produce food, wood, and other products [6]. FAO [31] came to the same conclusion that benefits from agroforestry are usually reaped in the middle and long terms; hence, given the poverty of the farmers in the region; promotion of agroforestry should be accompanied by strong government support. However, this finding supports with Montagnini and Nair [32] and they identified economic benefits (product diversification), agronomic benefits (soil protection, control of pathogens, extended cropping season), and social benefits due to the practice of agroforestry [6].
This research study conducted in the coastal belt adjacent to Sundarbans at Satkhira district of Bangladesh found that middle-aged farmers practiced agroforestry mostly (46\%) (Fig. 1) and Sharmin, and Rabbi [33] found that middle-aged farmers (42.7\%) were mostly interested in adopting agroforestry with traditional practice in Jhenaidah District of Bangladesh which is similar to this result. Similarly, Sheikh et al. [6] showed that most of the respondents are middleaged $(45 \%)$ practise agroforestry in Jessore district of Bangladesh. The farmers $(28 \%)$ taken lease from other people who have no own land they are not interested in agroforestry (Fig. 2) and the same result observed that farmers $(23.53 \%)$ who generally take a lease for cultivation do not practice agroforestry in Jhenaidah District of Bangladesh [33]. All farmers practiced homestead agroforestry in the research area and further were found to be the most common agroforestry practice (39.28\%) in Faridpur district of Bangladesh. [34]. The systematic Agroforestry practice is being popular day by day in Monirampur Upazilla of Jessore district of Bangladesh [6]. Therefore, Talukder [24], indicates that more than 85 percent of the farmers given their opinion that agroforestry practices increase agricultural development through sustainable production in Bangladesh. A similar result was found in Jhenaidah District of Bangladesh where all farmers practice homestead agroforestry [33]. Other results illustrated in Jessore district of Bangladesh that the respondents preferred homestead agroforestry (55\%) [6]. Nurunnahar et al. [35] found in Kaligong, Bangladesh that, most of the respondents were middle-aged farmers, male, and practice homestead agroforestry. Homestead agroforestry or home garden is being more popular by the respondents in the research area [6]. Gautam et al. [11] reported that home garden contributed $60 \%$ of the total consumption of agroforestry in India. Another study conducted in the north-eastern Atlantic forest biome in Brazil by Klie [36] revealed that most of the farmers $(89 \%)$ working with agroforestry systems generate more income than working with conventional agriculture and they also showed positive views on livestock under tree crops [6]. It is evident that and also reported by Prihaar et al. in 2015 [37] in Kumaun, India in case of homestead agroforestry. Another result revealed that the majority of primary educated respondents are involved in agriculture with medium size family mostly practiced mixed agroforestry around homestead along with livestock under tree cover, tree crop association, boundary plantation, woodlot agroforestry through possessing more favourable attitudes which ensure environmental, social, economical, biological benefits, enhance livelihood pattern, security, employment, household income etc. [6].

Attitudes, subjective norms, and perceived control were found to positively influence farmers' intentions to use rice variety innovations in India [38], to use improved grassland management practices in Brazil and Mexico [39], [40], to manage riparian and water-zone areas sustainably in Australia [41] and to adopt sustainable practices in paddy production in Malaysia [42]. Attitudes, past behaviour, and cultivated acreage size were found to be significant factors in the intentions to adopt sustainable practices in Italy, while subjective norms and perceived controls were insignificant motivators [43]. Studies in Iran also showed that attitudes, 
perceived risks, subjective norms and moral norms positively influenced the intentions of farmers to use water conservation practices [31], and attitude was found to be a significant factor in farmers' intentions to use climate information in farming practices, while subjective norms and perceived control were not found significant [44]. The mean scores for attitude and subjective norms towards environmentally oriented behaviours were higher for organic farmers than conventional farmers, but the opposite held true for production-oriented behaviours [45], [46]. Wauters [46] found that in Belgium, attitudes and perceived control were insignificant factors in affecting the intentions of farmers to adopt reduced tillage and buffer strips, while subjective norms were found to have a positive significant influence on both sustainable practices. In the Czech Republic, attitudes, and perceived control, along with education and age, have explained intentions to use agricultural technologies [19]. Several studies found a positive relationship between farmers' attitudes and perceptions towards environmentally sustainable programs [47]-[51]. About $68.7 \%$ of respondents have taken positively agroforestry practice, but they have no training skill or facility (Fig. 5). Another study conducted in Jhenaidah District of Bangladesh said that above $80 \%$ respondents have taken positively agroforestry practice but did not receive formal training skills or facility but just inherited ideas from their superiors [33]. Furthermore, remarkable proportion of the farmers (44.2\%) thinks positively about agroforestry systems. They believed that Agroforestry does not hamper their traditional Agricultural system and it has a great role in managing, space utilization, and recreational role and to meet their demands of wood, firewood, and other forest products. $21.57 \%$ of respondents strongly agreed with this point of view [33]. To add to this majority $(65 \%)$ of farmers negatively perceived because of not having ample technical support in agricultural practices Trinidad, West Indies [55]. Therefore, Saha et al. [34] revealed that, raising awareness regarding the benefits of agroforestry practices as well as providing technical assistance. Agroforestry practices offer practical ways of applying various specialized knowledge and skills to the development of rural production systems [6]. On the other hand, only $6.86 \%$ of farmers are not eager to practice the agroforestry system because of lack of knowledge on agroforestry systems, lack of technical assistance in Jhenaidah District of Bangladesh [33]. At the same time respondents must be more educated and conscious regarding technical skills and climate-vulnerable coastal of Sundarbans in Satkhira can be an important aspect of knowledge regarding the practice of Social Forestry [9]. Most of these reasons were also reported by Kittur and Bargali [52] in India.

Similarly, studies conducted by Agbarevo and Obinne [27] indicated that farmers in Nigeria found extension services to be ineffective and thus, were perceived negatively. In contrast, Ogunjimi and Farinde [53] observed that cacao farmers in Nigeria had poor knowledge levels with regards to precautionary measures in agrochemical usage and concluded that this shortcoming in knowledge was attributed to the lack of contact with extension officers. Most of the farmers $(68.7 \%)$ have a positive attitude towards agroforestry practice in Satkhira district of Bangladesh (Fig. 7) which is relevant to the results of Trinidad, West Indies where the majority $(75 \%)$ of farmers had fairly positive attitudes towards agricultural practices [54]. Similarly, according to Sheikh et al. [6], the majority of respondents (64\%) showed more favourable attitudes and $29 \%$ of respondents showed favourable attitudes towards agroforestry in Jessore district of Bangladesh. Furthermore, majority of the farmers (94.12\%) in Jhenaidah of Bangladesh had 'favourable' attitude towards agroforestry [33]. These findings correlate with BOMEL [54] who found that farmers in England had an overall positive attitude towards safe agricultural practices Trinidad, West Indies [54]. Result mentioned that $76.25 \%$ respondents perceived agroforestry positively towards agroforestry practice in Satkhira district of Bangladesh (Fig. 4) and maximum farmers $(80 \%)$ think the agroforestry system should be expanded (Fig-6). In another study conducted by Sheikh et al. [6], the majority $80 \%$ of respondents get all benefits (environmental, social, economic, and biological) due to the practice of agroforestry in Jessore district of Bangladesh. Farmer's perception towards agroforestry systems has been studied previously using interviews or surveys. A recent study was conducted by Garc1'a de Jalo'n et al. [29] covering different agroforestry systems in 11 European countries to capture the perception of stakeholders and key factors including farmers, landowners, agricultural advisors, researchers, and environmentalist towards agroforestry. When given the same list of 45 issues related to production, management, the environment, and socio-economic issues, the stakeholders ranked improved biodiversity and wildlife habitat, animal health, and landscape aesthetics as the main positive aspects of agroforestry [29]. The majority of the respondents in the study area were aware of the positive impact of agroforestry practices [34]. The respondents were aware of the economic and productive benefits of agroforestry practices and had favourable perception towards those practices. Most of the farmers $(90 \%)$ in Jessore district of Bangladesh get security, employment generation, and household income which accelerate their livelihood pattern due to the practice of agroforestry [6]. It is evident that significant proportion of respondents ( $82.14 \%$ on average) perceived agroforestry as a practice that can improve their farm productivity and overall income in comparison to monoculture [34].

Agroforestry can provide the next step in sustainable agriculture by promoting and implementing integrated, biodiversity processes [55]. However, the success of agroforestry practices is determined by the level of adoption of agroforestry by the farmers [34]. An estimated 1.2 billion people in developing countries rely on agroforestry practices to sustain their agricultural productivity and income [16]. A large body of the literature on the variables influencing the adoption of agroforestry practices exists, with a real explosion of research since the early 1990s [56]. More recently, studies have also looked at socio-psychological factors, such as perceptions and attitudes, to explain adoption behavior [23]. Meijer et al. [23] examine adoption studies which have attempted to explain agroforestry adoption behavior by linking it to farmers' perceptions and attitudes to improve adoption of sustainable practices by smallholder farmers, attention should be given to socio-psychological issues. This could lead to improvements in farm productivity and enhance the livelihoods of smallholders [24]. The 
adoption of younger (26-35) 35\% farmers is increasing day by day, since they have had more schooling than the older generation or perhaps have been exposed to new ideas as a migrant (Fig. 1) in the research area. Similar result was observed in Faridpur district where the majority of respondents (47\%) were young aged for adaptation [34]. Illiteracy $(56 \%)$ has a primary level of education) is the main reason for the non-adoption of agroforestry (Table II) in the research area. In the study area last 1-3 years (76\%) the adoption to agroforestry is higher than last 4-5 years $(22.5 \%)$ (Table VII) which indicates that farmers have observed they also involved agroforestry practice in this way agroforestry practice becoming popular in Satkhira district. Findings showed that, on an average significant proportion of farmers $(64.28 \%)$ have adopted agroforestry practice [57]. The main reason for the high level of adoption may be because of multiple benefits gained by the farmers from the crop-tree combination and also because agroforestry has been an ageold practice among the local farmers not only in the study area but also in the number of districts in the country. However, this finding supports [57]. At the same time, farmers' associations should be bolstered [6]. Mekoya et al. [57] found that agroforestry technologies are knowledgeintensive and therefore require enough education in the adoption process. Similar study conducted in Jessore district of Bangladesh mentioned that some farmers require training, technical facilities, etc. on different agroforestry systems [6]. Another study conducted in coastal areas mentioned vigorous tree growth which is important considering the necessity of agroforestry-related plantation [59]. The successful adoption of agroforestry to raise farm productivity and overall income of the respondents in the study area depends on raising awareness on benefits of agroforestry, providing adequate technical supports as well as ensuring the efficient use available farmlands of all types of landholders [34]. The adoption of the practice by younger generation of farmers (26-65) is improving from time to time perhaps due to access to modern education and exposure to new ideas as migrant [33]. By adopting new technology ultimately increase agroforestry production to accelerate sustainability [6]. Besides, Dey et al., [60] mentioned policy formulation in terms of successful plantation by considering people's attitudes, which may work in both mitigation and adaptation of climate change in the coastal remote areas of Bangladesh. Finally, it can be mentioned that by adopting agroforestry in the coastal belt adjacent to Sundarbans, depletion of forest resources must be reduced, and positive perceptions-attitudes reinforced that such adaptation to agroforestry is sustainable which accelerates decision-making process of government and forest-dependent community must get permanent ample alternative source of livelihood.

\section{CONCLUSION}

Continuous increase in population and changing socioeconomic conditions have tremendous pressure on forest resources, massive deforestation for industrialization, rapid urbanization, and high population pressure on existing forestland agroforestry practice such as homestead forest, aqua silviculture, woodlot, trees in cropland is inevitable which help to increase forest, produce timber as well as reduce the food scarcity. Since the findings of the study pointed out that there is a scope for improving the perception level and creating a more favourable attitude of farmers towards agroforestry, development functionaries can intensify their efforts to achieve the increased perception and attitude level of farmers. It was found that there was a big gap in the full adoption of all recommended agroforestry practices. In order to bridge this, development agencies should further intensify the extension activities to motivate and adopt all the practices. The agroforestry has brought improvement in socio-economic and ecological conditions of farmers by generating employment, increasing family income, enhancing crop diversity, and reducing dependency on natural forests. Therefore, development agencies can use the success story of agroforestry to stimulate other farmers to attain both natural resource and socio-economic sustainability. Although there are some problems in the practice, but they must overcome them if the government helps them cordially. So, the government should try to help the farmer by producing seedlings, logistics, and financial support which encourage the farmer to continue the practice.

\section{REFERENCES}

[1] Islam A, Sharmin A, Biswas R, Dey T, Bachar BK et al., (2020). Utilization of Minor Forest Products of the Sundarbans in Bangladesh. Adv in Agri, Horti and Ento: AAHE126.https://kosmospublishers.com/utilization-of-minor-forestproducts-of-the-Sundarbans-in-bangladesh/.

[2] SA Mukul, MB Uddin, AZM Manzoor Rashid, J Fox, (2010). Integrating livelihoods and conservation in protected areas: understanding the role and stakeholder views on prospects for nontimber forest products, a Bangladesh case study. International Journal of Sustainable Development \& World Ecology 17 (2), 180-188.

[3] Zashimuddin, M., (2004). Community forestry for poverty reduction in Bangladesh. In Sim, H.C., Appanah, S. and Lu, W.M. (Ed.). Forests for Poverty Reduction: Can Community Forestry Make Money, FAO Regional Office for Asia and the Pacific (FAORAP), Bangkok, Thailand, pp 81-94.

[4] Poffenberger, M. (2000). Communities and forest management in South Asia (Ed.). IUCN, DFID and Asia Forest Network, Indonesia, pp. 35-46.

[5] FAO (2013). Advancing Agroforestry on the Policy Agenda: A guide for decision- health harms of industrial agriculture. Env Heal Persp 110(5). Retrieved August 23, 2012.Rome.

[6] Sheikh, R., Islam, M. A., Sharmin, A., Biswas, R., \& Kumar, J., (2021). Sustainable Agroforestry Practice in Jessore District of Bangladesh. European Journal of Agriculture and Food Sciences, 3(1), 1-10. https://doi.org/10.24018/ejfood.2021.3.1.150.

[7] Rahman M. M., (2017). Development of Homestead Forest and Environment to Support the Rural People Living Adjacent to the Sundarbans. Int. J. Bus. Soc. Sci. Res. 5(3): 37-44. Retrieve from http://www.ijbssr.com/currentissueview/14013211].

[8] Uddin, M.B. and Mukul, S.A., (2007). Improving Forest Dependent Livelihoods through NTFPs and Home Gardens: A case study from Satchari National Park. In Fox, J., Bushley, B., Dutt, S. and Quazi, S.A. (Ed.). Making Conservation Work: Linking Rural Livelihoods and Protected Areas in Bangladesh. East-West Center, Hawaii, USA and Nishorgo Support Project of the Bangladesh Forest Department, Dhaka, Bangladesh, pp. 13-35.

[9] Islam, M. A., (2019). Status of Social Forestry for the Socio-Economic Development in the Coastal Belt of Sundarbans. International Journal of Agriculture Innovations and Research (IJAIR), (India) Volume 8, $\begin{array}{llll}\text { Issue } 3, & \text { ISSN } & \text { (Online) }\end{array}$ https://www.ijair.org/administrator/components/com_jresearch/files/ publications/IJAIR_3115_FINAL.pdf.

[10] Helal Siddiqui, A.S.M. and Islam, M. A., (2019). Survivality and Growth Performance of Jarul (Lagerstroemia speciosa) in the Raised Land of Less Saline Water Zone in the Sundarbans. International Journal of Agriculture Innovations and Research (IJAIR), (India) Volume 8, Issue 2, ISSN (Online): 2316-1473. 144 150pp.https://www.ijair.org/index.php/issues?view=publication\&task =show\&id=1298.

[11] Helal Siddiqui, A.S.M. and Islam, M. A., (2020). Vegetation scenarios of artificially planted mangrove species in the Sundarbans as a tool to mitigate climate change issues in Bangladesh, Indian Forester, 146 (8): 
736-583, DOI: 10.36808/if/2020/v146i8/148406 ISSN: 0019-4816 eISSN: $2321094 \mathrm{X}$.

https://www.researchgate.net/publication/344650085.

[12] Chaffey, D.R.; Miller, F.R. and Sandom, J.H., (1985). A Forest Inventory of the Sundarbans, Bangladesh: Main Report. Project Report No. 140. Overseas Development Administration, London. 196 pp.

[13] Forestal (1960). Forest Inventory 1958-59 Sundarbans Forests. Oregon: Forestal International Incorporated.

[14] Dey, T., Kamruzzaman, M., Islam, M. A., Bachar, B. K. and Pitol, M. N. S., (2020). Attitudes of local people towards community based ecotourism in the Sundarbans. International Journal of Business, Management and Social Research, 09(02), 528535.https://doi.org/10.18801/ijbmsr.090220.55.

[15] Sourovi Z, Salah Uddin. S, and Masatok. (2010). The Open Forest Science Journal, 2010, 3, 38-44, Structure and Diversity of Homegarden Agroforestry in Thakurgaon District, Bangladesh.

[16] FAO, (2011). Facts and figures: people and forests [online]. Available from: http://www.fao.org/forestry/.

[17] Poverty Reduction Strategy Paper (PRSP) (2005), 'Unlocking the Potential'. National Strategy for A Comission, Government of the People's Republic of Bangladesh. Accelerated Poverty Reduction Bangladesh: General Economics Division, Planning.

[18] Tiwari, A.K. (1994). Mapping forest biomass through digital processing of IRS-1A data. International Journal of Remote Sensing, 15(9):1849-1866.

[19] Unseld R, Reppin N, Eckstein K, Zehlius-Eckert W, Hoffmann H, Huber T., (2011). Leitfaden Agroforst Systeme Möglichkeiten zur Naturschutzgerechten Etablierung von Agroforstsystemen. Gefördert durch Bundesamt für Naturschutz (BfN), p 48.

[20] Hanif MA; Amin; MHA; Bari MS; Ali MS and Uddin MN, (2010). Performance of okra under litchi based agroforestry system. J. Agrofor. Environ. 4 (2): 137-139.

[21] Sing, M. P. and D. N. Tewari, (1996). Agro forestry and wasteland, $1^{\text {st }}$ edition, Anmol publications private limited, New Delhi. PP-299.

[22] Reeg T, (2011). Agroforestry systems as land use alternatives in Germany? A comparison with approaches taken in other countries. Outlook Agric 40:45-50.

[23] Meijer S., Delia Catacutan, Oluyede C. Ajayi, Gudeta W. Sileshi\& Maarten Nieuwenhuis. (2015). The role of knowledge, attitudes and perceptions in the uptake of agricultural and agroforestry innovations among smallholder farmers in sub-Saharan Africa, International Journal of Agricultural Sustainability, 13:1, 40-54, DOI: 10.1080/14735903.2014.912493.

[24] Zeweld W, Van Huylenbroeck G, Tesfay G, Speelman S., (2016). Smallholder farmers' behavioural intentions towards sustainable agricultural practices. J Environ Manage. 2017 Feb 1; 187:71-81. doi: 10.1016/j.jenvman.2016.11.014. Nov 21. PMID: 27883941.

[25] Dabbs, Jr, J. M., and Leventhal. H., (1966). "Effects of Varying the Recommendations in a Fear-Arousing Communication." Journal of Personality and Social Psychology 4 (5): 525-531.

[26] Likert R, (1932). A technique for the measurement of attitudes. Archives of Psychology.140:1-55.

[27] Agbarevo MN, Obinne CPO, (2009). "An evaluation of the effect of agricultural extension delivery on cassava production in Nigeria: A Case Study of Cross-River State, Nigeria." The Niger. Agric. J. 39(1\&2):16-21. Agroforstschla“ge. Agrar Umweltr 1:7-12.

[28] Annual Report, I.I.T.A. (1997). Farmers' perceptions of soil degradation. International Institute of Tropical Agriculture. Lambourn UK. http://www.iita.org/info/ar97/26-27.htm.

[29] Garc1'a de Jalo'n S, Burgess PJ, Graves A et al., (2017). How is agroforestry perceived in Europe? An assessment of positive and negative aspects among stakeholders. AgroforSyst. https://doi.org/10.1007/s10457-017-0116-3.

[30] Gautam G, Mitchell R, and Hanstad T, (2004). Small homegarden plots and sustainable livelihoods for the poor. FAO-LSP, WP. p. 11.

[31] Yazdanpanah, M., et al., (2014). Understanding farmers' intention and behavior regarding water conservation in the Middle-East and North Africa: a case study in Iran. J. Environ. Manag. 135, $63 \mathrm{e} 72$.

[32] Montagnini F, Nair P.K.R., (2004). Carbon sequestration: An underexploited environmental benefit of agroforestry systems. Agroforestry Systems 61, 281-29.

[33] Sharmin A, and Rabbi SA, (2016). Assessment of Farmers' Perception of Agroforestry Practices in Jhenaidah District of Bangladesh. Journal of Agriculture and Ecology Research International6 (4): 1-10; Article no.JAERI.21760.ISSN: 2394-1073.

[34] Patt, A. G., and D. Schr€oter., (2008). "Perceptions of Climate Risk in Mozambique: Implications for the Success of Adaptation Strategies.” Global Environmental Change 18 (3): 458-467.

[35] Saha S; Sharmin A; Biswas R and Ashaduzzaman M, (2018). Farmers' Perception and Adoption of Agroforestry Practices in Faridpur District of Bangladesh. International Journal of Environment, Agriculture and Biotechnology (IJEAB). ISSN: 2456-1878, Vol-3, Issue -6.

[36] Nurunnahar, Pitol M. N. S., and Sharmin, A, (2020). Status and Prospects of Agroforestry at Kaligonj Upazila in Satkhira District EJFOOD, European Journal of Agriculture and Food Sciences Vol. 2, No. 6. DOI: http://dx.doi.org/10.24018/ejfood.2020.2.6.186.

[37] Klie MS., (2018). Agroforestry as a biodiversity conservation tool and the motivations and limitations for small scale farmers to implement Agroforesty systems in the north eastern Atlantic forest biome in Brazil.

[38] Parihaar R.S., Bargali K, Bargali S.S., (2015). Status of an indigenous agroforestry system: A case study in Kumaun Himalaya, India. Indian Journal of Agricultural Sciences. 2015;85(3):442-447.

[39] Yamano, T., Rajendran, S., Malabayabas, M., (2013). Determinants of Psychological Constructs toward Agricultural Technology Adoption: Evidence from Eastern India.

[40] Borges, J.A.R., et al., (2014). Understanding farmers' intention to adopt improved natural grassland using the theory of planned behavior. Livest. Sci. 169, 163e174. Case study in Kumaun Himalaya, India. Indian Journal of Agricultural Sciences. 85(3):442-447.

[41] Martínez-García, C.G., Dorward, P., Rehman, T., (2013). Factors influencing adoption of improved grassland management by smallscale dairy farmers in central Mexico and the implications for future research on smallholder adoption in developing countries. Livest. Sci. 152 (2e3), 228e 238.

[42] Fielding, K.S., et al., (2005). Explaining landholders' decisions about riparian zone management: the role of behavioural, normative, and control beliefs. J. Environ. Manag. 77, 12e21.

[43] Terano, R., et al., (2015). Factors influencing intention to adopt sustainable agriculture practices among paddy farmers in Kada, Malaysia. Asian J. Agric. Res. 9 (5), $268 \mathrm{e} 275$.

[44] Menozzi, D., Fioravenzi, M., Donati, M., (2015). Farmer's motivation to adopt sustainable agricultural practices. Bio-based Appl. Econ. 4 (2), $125 \mathrm{e} 147$.

[45] Sharifzadeh, M., et al., (2012). Agricultural climate information use: an application of the Planned Behaviour Theory. J. Agric. Sci. Technol. 14 (2), 479e492.

[46] Power, E.F., Kelly, D.L., Stout, J.C., (2013). Impacts of organic and conventional dairy farmer attitude, behaviour and knowledge on farm biodiversity in Ireland. J. Nat. Conserv. 21 (5), $272 \mathrm{e} 278$.

[47] Wauters, E., (2010). The Use of Social Psychology for Improving the Adoption of Conservation Practices Soil Conservation in Belgium. Faculty of Bioscience Engineering KU Leuven. PhD thesis.

[48] Herath, C.S., (2013). Does intention lead to behaviour? A case study of the Czech Republic farmers. Agric. Economics-Czech 59 (3), $143 \mathrm{e} 148$.

[49] Price, J.C., Leviston, Z., (2014). Predicting pro-environmental agricultural practices: the social, psychological and contextual influences on land management. J. Rural Stud. 34, $65 \mathrm{e} 78$.

[50] Veisi, H., Toulabi, S.B., (2012). Factors influencing proenvironmental behaviour in agriculture. In: International Conference on Ecological, Environmental and biological sciences. Environmental Sciences Reserach Institute, Dubai, pp 346e349. Shahid Beheshti University.

[51] Bayard, B., Jolly, C., (2007). Environmental perceptions and behavioral change of hillside farmers: the case of Haiti. J. Caribb. Agro-Economic Soc. 7 (1), 122e138.Biological Sciences. Environmental Sciences Research Institute, Dubai, pp. 346e349. Shahi Beheshti University.

[52] Jordan, J.L., (2005). Farmers' choice of using sustainable agricultural practices: a social capital approach. In: The Southern Agricultural Economics Association Annual Meeting, pp. 1e25. Arkansas.

[53] Kittur B., Bargali S.S., (2013). Perspectives of agroforestry: Present and future facets. Journal of Progressive Agriculture.4 (2):91-94.

[54] Ogunjimi SI, Farinde AJ, (2012). Farmers' knowledge level of precautionary measures in agro-chemicals usage on cocoa production in Osun and Edo States, Nigeria. Int. J. Agric. Forestry 2(4):186-194.

[55] Kurina, B., Wayne, G., \& Lendel, N., (2015). Farmer's knowledge, attitudes and perceptions of occupational health and safety hazards in Trinidad, West Indies and implications for the Agriculture sector. Journal of Agricultural Extension and Rural Development, 7, 221-228.DOI: 10.5897/JAERD2015.0672.

[56] Wilson, M. and Lovell, S. (2016). Agroforestry - The Next Step in Sustainable and Resilient Agriculture. Sustainability, 8(6), 574 doi:10.3390/su8060574.

[57] Mercer, D., (2004). Adoption of agroforestry innovations in the tropics: a review. Agroforestry systems, 61 (1).

[58] Mekoya, A.K., Oosting, S.J., Fernandez-Rivera, S., Van der Zijp, A.J., (2008). Farmers' perceptions about exotic multipurpose fodder trees and constraints to their adoption. Agroforestry Systems 73:141-153. 
[59] De, T., Ahmed, S, Islam M. A., (2021). Relationships of tree heightdiameter at breast height (DBH) and crown diameter-DBH of Acacia auriculiformis plantation. Asian journal of forestry, E-ISSN: 25802844, DOI: $10.13057 /$ asianjfor/r050203, Pages: 71-75.

[60] De, T., Rajib, M. G. M. Islam M. A., (2021). People's Perceptions about the Socio-Economic and Environmental Impact of Coastal Green Belt in Bangladesh. Indonesian journal of social and environmental issues (IJSEI), Vol-2, Issue-2, and DOI: 10.47540/ijsei.v2i2.280, pp: $155-162$.

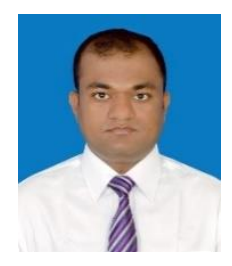

Md. Akramul Islam was born in Tala, Satkhira, Bangladesh and completed his B.Sc. (Hons.) and M.Sc. in Forestry from Khulna University, Khulna, Bangladesh. During his study period he studied different subjects related to Forestry especially in Mangrove related areas. He was appointed as a Research Officer (RO) at Mangrove Silviculture Division under the Bangladesh Forest Research Institute on the $27^{\text {th }}$ December, 2018 by the recommendation Bangladesh Public Service Commission (BPSC) of the People's Republic of Bangladesh and working till date. Besides he is sincere, modest, and honest in his field as a researcher.

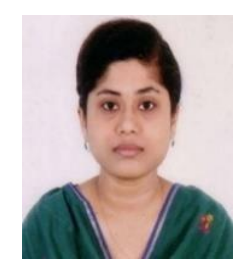

Laila AbedaAktar is a Research officer at Bangladesh Forest Institute, Chattogram. She received her B. Sc. (Hons.) in Forestry (2005) and M. S. in Forestry (2009) from University of Khulna, Bangladesh. She is working as an active researcher in the various problems and study areas in forestry research, especially silvicultural management. Her current interests are forest management, agroforestry and medicinal plants based research work. She has eight research papers published in Bangladesh Journal of Forest Science, International Journal of Sustainable Agricultural Technology (IJSAT), International Journal of Business, Social \& Scientific Research (IBSSR) and International Journal of Social Development \& Information System (IJSDIS). She is a member of Institution of Foresters Bangladesh.

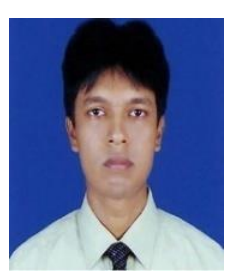

S. M. Rakibul Jubair is a Research officer at Bangladesh Forest Institute, Chattogram. He received his B. Sc. (Hons.) in Forestry (2006) and M. S. in Forestry (2010) from University of Khulna, Bangladesh. He is working as an active researcher in the various problems and study areas in forestry research. His current interests are soil conservation \& watershed management, forest products and medicinal plants based research work. He has six research papers published in International Journal of Social Development \& Information System (IJSDIS), Evidence-Based Complementary and Alternative Medicine, Bangladesh Journal of Forest Science and International Journal of Business, Social \& Scientific Research (IBSSR). He is a member of Institution of Foresters Bangladesh

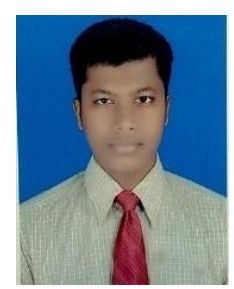

Tanmoy Dey is a Research Officer of Plantation Trail Unit Division under Bangladesh Forest Research Institute (BFRI), Barishal. He completed his B.Sc. (Hons.) \& M.Sc. course in Forestry and Wood Technology Discipline, Khulna, Bangladesh. In field survey and laboratory analysis as he worked as a researcher properly during his study period. He also participated in different training such as Research Methodology, Development Project Processing Management, Innovation and Service Process Simplification (SPS) Workshop etc. and also got some training on disaster management and environment related issues in different time.

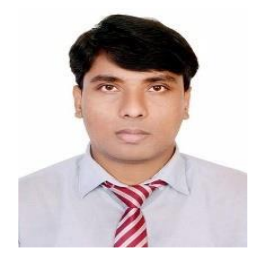

Rahul Biswas completed his B. Sc (Hons) and M.Sc. in Forestry from Forestry and Wood Technology Discipline of Khulna University, Bangladesh. He is an expert of sample testing, data analysis, report writing, scientific paper writing and published article in various international journal. At present he is working as Management Trainee Officer in Arbab group, Bangladesh. 